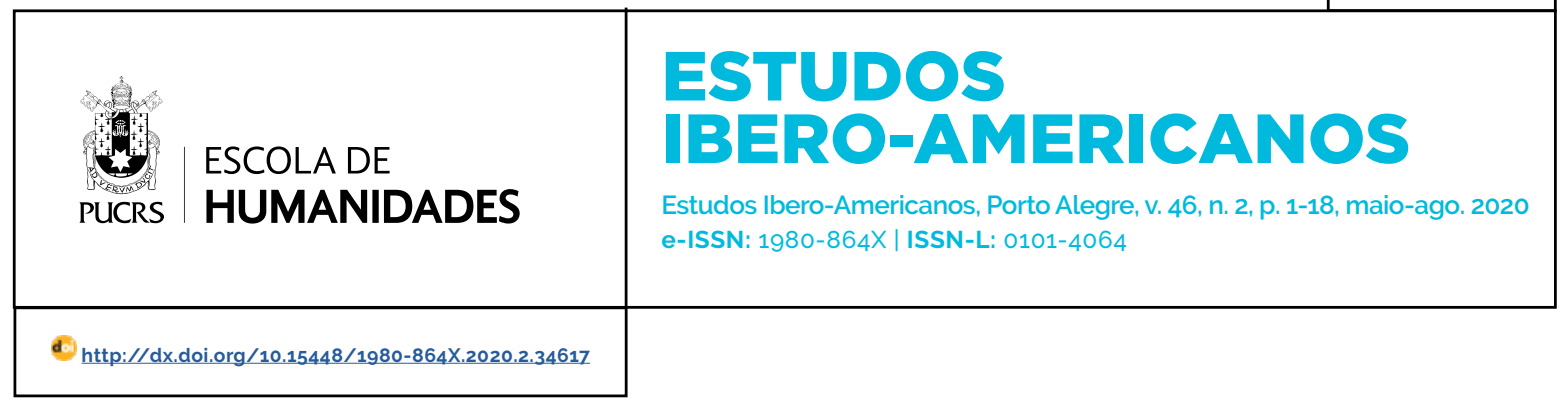

SEÇÃO: DOSSIÊ IMPRENSA, CULTURA E CIRCULAÇÃO DE IDEIAS

\title{
Experiências de Rafael Bordalo Pinheiro (1846-1905) no Brasil: O Mosquito (1875-1877)
}

\author{
Experiencias de Rafael Bordalo Pinheiro (1846-1905) en Brasil: O Mosquito (1875-1877) \\ Experiences of Rafael Bordalo Pinheiro (1846-1905) in Brazil: O Mosquito (1875-1877)
}

\section{Rosangela de Jesus}

Silva ${ }^{1}$

orcid.org/0000-0001-9315-7696

rosangelad@gmail.com

Recebido em: 1 jul. 2019.

Aprovado em: 17 mar. 2020.

Publicado em: 25 ago. 2020
Resumo: A decisão do caricaturista português Rafael Bordalo Pinheiro de ir trabalhar no Brasil em 1875 apresentou desafios e experiências importantes para a carreira do artista. Em sua atuação no jornal ilustrado e satírico O Mosquito (1869-1877) precisou dialogar e conquistar o público de um país que, embora culturalmente próximo de Portugal, tinha suas particularidades. Conviveu com outros caricaturistas, compartilhou vivências e experimentou um meio jornalístico competitivo, por vezes, hostil à sua condição de "estrangeiro". A partir do conceito de "transferência cultural" o qual propõe analisar as relações entre a América Latina e a Europa sob perspectiva não hierárquica, mas enquanto "intercâmbios multilaterais" (COMPAGNON, 2005), a proposta do artigo é analisar algumas das estratégias de Bordalo em seus momentos inicias no Brasil, assim como seus diálogos com outros artistas e periódicos ilustrados.

Palavras-chave: Imprensa ilustrada. Brasil. Século XIX. Rafael Bordalo Pinheiro.

Resumen: La decisión del caricaturista portugues Rafael Bordalo Pinheiro de trabajar en Brasil en 1875 presentó desafios y experiencias importantes para la carrera del artista. En su colaboración en el periódico ilustrado y satírico 0 Mosquito (1869-1877) fue necesario conquistar al público de un pais que, aunque culturalmente cercano a Portugal, tenía sus peculiaridades. Convivió con otros caricaturistas, compartió vivencias y experimentó un medio periodístico competitivo, a veces hostil a su condición de "extranjero". A partir del concepto de "transferencia cultural" el cual propone analizar las relaciones entre América Latina y Europa desde una perspectiva no jerárquica, pero como "intercambios multilaterales" (COMPAGNON, 2005), la propuesta del artículo es analizar algunas de las estrategias de Bordalo en sus momentos iniciales en Brasil, así como sus diálogos con otros artistas y periódicos ilustrados.

Palabras clave: Prensa ilustrada. Brasil. Siglo XIX. Rafael Bordalo Pinheiro.

Abstract: The decision of the Portuguese caricaturist Rafael Bordalo Pinheiro to go to work in Brazil in 1875 presented challenges and important experiences for the career of the artist. In his performance in the illustrated and satirical newspaper O Mosquito (1869-1877) he had to dialogue and conquer the public of a country that, although culturally close to Portugal, had its peculiarities. He lived with other caricaturists, shared experiences and experimented with a competitive journalism, sometimes hostile to his "foreign" status. From the concept of "cultural transfer" which proposes to analyze the relations between Latin America and Europe under a non-hierarchical perspective, but as "multilateral interchanges"(COMPAGNON, 2005), the proposal of the article is to analyze some of Bordalo's strategies in his early moments in Brazil, as well his dialogues with other artists and illustrated periodicals.

Keywords: Illustrated press. Brazil. 19th Century. Rafael Bordalo Pinheiro. 


\section{Introdução}

"Nunca cursei academias. Tenho o curso da Rua do Ouvidor...cinco anos. Canto de ouvido".? $\mathrm{Na}$ frase atribuída a Rafael Bordalo Pinheiro por volta de 1903 é mencionada a rua que foi o centro da vida social do Rio de Janeiro no século XIX. Na mesma rua estiveram instaladas as redações das publicações nas quais atuou no País: O Mosquito (1875-1877), Psit!! (1877) e O Besouro (1878-1879).3 A memória do Brasil evocada na frase indica que a experiência brasileira foi relevante para o artista, sobretudo porque foi dita em um momento de maturidade, anos depois do seu retorno. Os cerca de quatro anos (1875-1879) que passou no Brasil foram mencionados por vários estudiosos do artista em termos que evocam ideias de aperfeiçoamento, formação e amadurecimento. Para João Paulo Cotrim "Os anos brasileiros são de formação. Aperfeiçoa-se a técnica, consolida-se um universo, criam-se personagens e aprofundam-se outras como o Zé Povinho" (COTRIM, 2005, p. 74). ${ }^{4}$ JoséAugusto França comenta que "Nas páginas d'O Besouro afinou-se o seu talento de desenhador e nelas ficaram registadas algumas ideias que viria a aproveitar-se ou a repetir em seus jornais lisboetas" (FRANÇA, 2007, p. 82). E Herman Lima em sua História da Caricatura no Brasil escreve que "Foi no Brasil, efetivamente, que as suas melhores qualidades de desenhista espontâneo e imaginoso [...] se expandiram em tôda a pujança, amadurecendo ao sabor da multidão de assuntos oferecidos à sua observação e ao seu reparo" (LIMA, 1963, p. 892).

Apesar das afirmações que reconhecem a relevância desse periodo, a fase brasileira ainda tem muito que ser estudada e aprofundada, pois muitas vezes foi apenas citada como um breve capítulo da vida de Bordalo. Felizmente há, nos últimos anos, trabalhos que avançaram na análise da fase brasileira. Alguns apontam para o inicio de propostas que frutificaram ao longo da produção gráfica do artista, outros mostram as conexões que o artista criou entre Portugal e o Brasil. A fim de exemplificar, citamos o livro de Maria Vergílio C. Lopes Rafael Bordalo Pinheiro - imagens e memórias do teatro, de 2013, no qual a autora ao analisar as relações entre o teatro e a política como elementos constantes na obra de Bordalo inclui os periódicos brasileiros em seu trabalho.

Para a autora Bordalo começaria n'O Besouro "de forma sistemática, a servir-se do teatro como metáfora explicativa da situação política e social" (LOPES, 2013, p. 134-135). A tese de doutorado de Rômulo de J. F. Brito, defendida em 2017 no Brasil, propõe discutir a presença do Brasil na obra caricatural de Bordalo, tendo por base as relações entre Brasil e Portugal. O autor apresenta um percurso pela produção caricatural do artista demonstrando que sua passagem pelo Brasil teria "sido a base para a construção de ideias que levaria e aplicaria nos demais periódicos por ele criados em Portugal" (BRITO, 2017, p. 22). Além disso, Brito afirma que o Brasil na obra de Bordalo seria "um eixo de reflexão transnacional", um "instrumento para pensar a sociedade portuguesa e, por outro lado, tendo sua interpretação influenciada pelas concepções do autor sobre Portugal, em um constante processo de interlocução" (BRITO, 2017, p. 350). A tese de Danilo W. Ferrari, também defendida no Brasil em 2018, analisa os diálogos que existiriam entre a obra gráfica de Rafael Bordalo Pinheiro e a produção do escritor brasileiro Monteiro Lobato (1882-1948). O autor propõe a análise de Bordalo como um "passeur", segundo as próprias palavras do autor um "mediador em contato com diferentes culturas" (FERRARI, 2018, p. 26). Evoca-se a ideia, que aqui nos interessa particularmente, de "transferência cultural", daquele que traz, mas também leva, que ensina e aprende, em um movimento contínuo entre diversos contextos culturais. Para o autor Bordalo "trouxe inovações que deixaram marcas na história da imprensa brasileira, mas também teve sua obra modificada, ao retornar a Portugal" (FERRARI, 2018,

\footnotetext{
PINTO, 1915, p. III.

O periódico O Mosquito começou a ser publicado no Rio de Janeiro em 1869, mas o presente artigo só analisará o período no qual Rafael Bordalo Pinheiro atuou no mesmo, ou seja, de 1875 a 1877.

4 Essa personagem foi criada por Bordalo em 1875 no jornal ilustrado A Lanterna Mágica (1875), publicada em Lisboa. "Zé Povinho" que se tornaria símbolo do povo português, figurou na obra gráfica e cerâmica do artista ao longo de toda a sua carreira.
} 
p. 26). Nos alinharemos aos interesses desses autores em analisar e enfatizar a importância da passagem do artista pelo Brasil.

Sendo o olhar algo tão fundamental para o trabalho do caricaturista, o que Bordalo teria visto nesses anos? O que o interessou e foi, portanto, aproveitado, deglutido? Com quem lidou no meio jornalístico, sobretudo na imprensa ilustrada satírica? Quais eram as grandes questões com as quais teve de enfrentar-se? Embora seja dificil responder todas essas indagações, elas podem contribuir para olhar a obra de Bordalo nesses anos de maneira crítica e comparativa. Colocála em perspectiva com o contexto da produção caricatural e com os artistas do lápis que atuavam no Brasil naquele momento, bem como com os temas e demandas contemporâneas. Nossa hipótese é a de que o ambiente "competitivo" da imprensa ilustrada, a necessidade de dialogar com o público e com seus colegas do lápis, bem como em firmar seu nome em um meio, por vezes, hostil, levaram o artista a buscar estratégias que evocaram tanto sua condição de artista europeu quanto do reconhecimento de singularidades locais com as quais precisava dialogar. ${ }^{5}$ Ou seja, seu percurso até então havia lhe dado bases importantes, mas que exigiam também novas aprendizagens, as quais foram construidas em sua convivência com os colegas de profissão alguns experientes como Luigi Borgomainerio (ca.1834-1876) e Angelo Agostini (1843-1910) - e com a necessidade de dar respostas às demandas contemporâneas e locais. ${ }^{6}$ Certamente há muitos mais elementos fora do universo da imprensa ilustrada que não serão aqui discutidos, no entanto parece um caminho frutífero olhar as revistas mais importantes em circulação e alguns dos artistas com quem possa ter colaborado.

Essa pesquisa apresenta-se também como possibilidade de reavaliar e problematizar a contribuição e recepção da produção europeia na América Latina e vice-versa. A relação Europa-América foi apresentada durante muito tempo como uma estrada de mão única. O conhecimento transitaria do "Velho" para o "Novo mundo", em uma relação passiva e mesmo de anulação do outro. Alguns percursos teóricos apontam para pensar essa relação de maneira mais equilibrada e problematizada através, por exemplo dos: Estudos Subalternos; Pós-Coloniais; Histórias Conectadas; História Global; Histórias Transnacionais; Transferências Culturais, entre outros". Ou seja, estudos que chamam a atenção para a circulação do conhecimento através de conexões e compartilhamentos em uma via de mão dupla, em perspectiva não hierarquizada.

O conceito de Transferência Cultural, que auxiliará no desenvolvimento do presente texto, surgiu nas últimas décadas do século $X X$ na França para pensar as relações franco-alemãs. Os autores que o desenvolveram foram Michel Espagne e Mickael Werner em um texto intitulado "Transferts. Les relations interculturelles dans l'espace franco-allemand" (XVIII-XIX siècles), publicado em 1988 e aprofundado por Espagne em 1999. Segundo Diana Cooper-Richet o objetivo deste estudo foi "montrer comment ces emprunts étaient reçus - étude de la réception - par la société d'accueil, c'est-à-dire les emprunts à la culture allemande en France et ceux de la culture française en Allemagne" (COOPERRICHET, 2013, p. 129). A autora propõe que o conceito de Transferência Cultural aliado ao de "passeur de culture" (mediador cultural) sejam ferramentas para repensar a circulação das ideias, do conhecimento e das práticas entre os dois continentes. Outro autor que também se debruça sobre essas questões e defende o conceito de Transferência cultural para pensar a América Latina é Olivier Compagnon. Em artigo de 2005, discute problemas metodológicos que os conceitos de Influência e Modelo apresentariam

\footnotetext{
5 A partir de 1860 aumentou a produção dos periódicos ilustrados no Brasil, entre outros motivos, pela difusão da litografia. Durante a estadia do caricaturista português no Brasil circulava, entre outros: A Semana Illustrada (1860-1876); O Mequetrefe (1875-1892); O Mephistopheles (1974-1875); A Vida Fluminense (1868-1875); O Figaro (1876-1877); A Revista Illustrada (1876-1898), entre outros.

6 Rafael Bordalo Pinheiro já desenvolvia uma carreira promissora em Portugal antes de vir ao Brasil. Atuou em publicações como $O$ Binóculo (1870), O Calcanhar de Aquiles (1870), A Berlinda (1870-71), A Lanterna Mágíca (1875), além de álbuns de caricaturas como A Picaresca Viagem do Imperador de Rasilb (1872), sobre a viagem de D. Pedro II a Europa. O artista também colaborou em periódicos estrangeiros como El Mundo Cómico; Ilustración Española y Americana e El Bazar e The Ilustrated London News.
} 
nos estudos das relações culturais entre Europa e América Latina por subentenderem uma "dominação cultural". Propõe que o conceito de Transferência Cultural contribuiria para pensar a circulação de ideias em termos mais complexos, como "intercâmbios multilaterais", de "vaivém", não lineares. Além disso, também aponta para pensar essas relações para além de bilateralismos, já que os mediadores culturais trazem inúmeras outras referências para além de seus contextos nacionais:

En reconstituant les itinéraires personnels des passeurs culturels, en identifiant des réseaux de personnes qui se forment au cours du processus de diffusion d'un produit, en décrivant les sociabilités nouvelles découlant de ces réseaux, un certain nombre de recherches ont montré que les processus de diffusion d'un point à un autre n'étaient que rarement linéaires (COMPAGNON, 2005, p. 18).

Com o objetivo de avançar e aprofundar a discussão, em 2009 o autor escreveu o artigo "L'Euro-Amérique en question. Comment penser les échanges culturels entre l'Europe et l'Amérique latine". Nesse trabalho, além de afirmar ideias apresentadas em 2005, busca reforçar seu argumento com exemplos. O autor cita os processos de implantação de repúblicas em várias "jovens nações" americanas no século XIX, as quais teriam se dado de forma mais "estável" do que na França. Prossegue, ainda, com exemplos no século $X X$, nos quais elementos da dança e da música latino-americanas teriam alterado práticas europeias e, particularmente, francesas.

Tania Regina de Luca em artigo, publicado em 2014, no livro A circulação transatlântica de impressos: Conexões questiona a ideia de uma recepção passiva apenas como reflexo de modelos importados. A autora, em outros trabalhos, chama a atenção para como a imprensa, pelo seu "alto grau de internacionalização", assim como por sua produção coletiva e capacidade de circulação por "espaços transnacionais" (LUCA, 2012, p. 11), seria um campo frutifero para esse tipo de abordagem. Luca comenta como seria interessante estudar o caso de Rafael Bordalo Pinheiro em sua passagem pelo Brasil. Ou seja, a experiência brasileira do caricaturista português poderia ser analisada "em termos de trocas e intercâmbios, em diferentes direções e sentidos" (LUCA, 2014, p. 171). Em acordo com a proposição da autora e, dos trabalhos acima citados, buscaremos apresentar o percurso de Bordalo Pinheiro sob as perspectivas que o conceito de Transferência Cultural propicia ao pesquisador. Queremos olhar o percurso de Bordalo Pinheiro como do mediador cultural que ao chegar ao Brasil trouxe, além de sua experiência portuguesa, passagens e colaborações em outros paises. Mas também daquele que neste país encontraria outros mediadores culturais em um ambiente jornalistico desafiador.

\section{O convite para trabalhar no Brasil}

A contratação de Rafael Bordalo Pinheiro pela folha ilustrada brasileira O Mosquito foi acertada por carta em 1875.7 Uma carta foi do proprietário da publicação Manoel Rodrigues Carneiro (18--?) e outras duas foram do português, emigrado para o Brasil, e amigo de Rafael, Alfredo Camarate (18401904). ${ }^{8}$ Nas cartas que Bordalo recebeu, além da oferta de trabalho e as supostas vantagens dessa, alguns elementos ajudam a perceber como o país e o ambiente de trabalho foi apresentado ao artista. Tal apresentação, embora confrontada com o que o caricaturista experenciou, certamente contribuiram para formar ideias iniciais com repercussões sobre seu trabalho.

O Brasil é apresentado por Manuel Carneiro como "um cantinho de Paris, e o resto... do Porto. [...] juntando-lhe mais uns arrabaldes admiráveis, mesmo para lisboetas." O grande inconveniente era a febre amarela, mas esta seria "uma moléstia que só ataca os imprudentes e os medrosos: com algumas pequenas prevenções e cautelas, nada há a temer" (CARNEIRO, 1875). Camarate também

As cartas aqui citadas estão na coleção do Museu Rafael Bordalo Pinheiro (MRBP), em Lisboa.

8 Alfredo Camarate teria chegado ao Brasil em 1872, aos 32 anos e permanecido até seu falecimento em 1904. Segundo Pedro C. Luscher (2011) sua formação teria ocorrido no Reino Unido e sua atuação profissional nos campos da engenharia, arquitetura, jornalismo e música. Foi conservador do Museu de Arte Ornamental da Academia Real de Belas Artes de Lisboa. No Brasil colaborou em periódicos no RJ, SP e MG. Tocava flauta, compunha para piano e foi crítico musical. Além disso, atuou como engenheiro na construção de Belo Horizonte. 
fala sobre a febre amarela, aconselhando o amigo a chegar antes do verão, meses nos quais a febre atacaria os recém-chegados. Quanto ao país, Camarate prefere falar dos brasileiros: "O povo brasileiro tem um amor pátrio [...] exagerado. [...] Para os brasileiros a sua esquadra é superior à inglesa, os seus pintores superiores a Rafael e ao Ticiano, o seu Carlos Gomes excede Mozart e Meyerbeer [...]" (CAMARATE, 1875). Camarate amenizaria a informação afirmando que esses "excessos" seriam "desculpaveis nos povos ainda novos". Manuel Carneiro idealizaria o país juntando nele as cidades que julgava serem apreciadas por Bordalo a fim de convencê-lo a viver no Brasil. Camarate, embora fale dos inconvenientes da febre amarela e da mania de exagero dos brasileiros, não deixa de animar o amigo, apresentando soluções aos problemas apontados. Afinal, falar de exagero como característica dos nacionais para um caricaturista era oferta de rico manancial a ser explorado.

Além das linhas dedicadas a convencer Bordalo acerca das peculiaridades do Brasil (CARNEIRO, 1875; CAMARATE, 1875), o argumento mais forte e, mais desenvolvido, deu-se em torno das vantagens e qualidades do periódico que o contrataria. Tanto Carneiro quanto Camarate ressaltaram os benefícios financeiros do empreendimento. Carneiro apresenta números e fala dos 2200 assinantes com o qual já contavam. Avança, ainda, proclamando possibilidades de expansão através de propaganda que outro empreendimento do editor, a Gazeta de Notícias (1875-1942), poderia aportar ao O Mosquito. Camarate, além de falar das vantagens do contrato e do bom salário, chama a atenção do amigo para detalhes das cláusulas, incluídas por sua intervenção, que abriam ao artista possibilidades de participação nos lucros, futura sociedade, bem como permitiria que Bordalo, sem comprometer seu trabalho no periódico, pudesse "augmentar consideravelmente os seus meios de receita, desenhando tudo quanto lhe aparecer"
(CAMARATE, 1875). Para Carneiro e Camarate, ao aceitar trabalhar n'O Mosquito, Bordalo teria algo essencial e desejável ao trabalho do caricaturista: independência e liberdade. Carneiro afirma que

A grande questão é mantê-lo 10 Mosquito] na independência de opinião em que eu o criei, e da qual se apartara um pouco, bem contra minha vontade. nestes últimos tempos. Felizmente, o mal está cortado e ainda tem remédio, remédio fácil com um colaborador da sua força (CARNEIRO, 1875).

E Camarate afirma que "É O Mosquito o único jornal que tem ousado dizer as verdades ao povo brasileiro, e de tal modo o tem educando, que ninguém acreditaria, ha meia dusia de annos passados que se diria no Brasil o que este jornal tem dito" (CAMARATE, 1875). Há nessas afirmações elementos importantes e que impõem responsabilidades a Bordalo. O jornal possuía uma trajetória consolidada e respeitada pelo público. Logo, o caricaturista não apenas tinha que continuá-la, mas também recolocá-la no caminho da "verdade", já que a publicação teria desviado "um pouco". Mas o que teria desviado a "independência de opinião" do jornal ilustrado? Para responder, recuamos às primeiras linhas da carta de Carneiro, na qual fala do rompimento de sua sociedade com Angelo Agostini, sócio e principal ilustrador do periódico entre final de 1871 e meados de 1875. Para Carneiro, o fim da parceria teria ocorrido porque: "o Sr. Agostini mordeu o fruto proibido dos trabalhos do Governo e não pode usar, na sua análise da imparcialidade que o público estava acostumado conosco" (CARNEIRO, 1875). Foi plantada aqui a primeira "semente da discórdia" entre Bordalo e Agostini, que tomaria vulto nas páginas de suas publicações ao longo da estadia do caricaturista português no Brasil. ${ }^{9}$ Apesar da ressalva de Carneiro, Agostini era um nome respeitado no meio jornalístico brasileiro, assim como também teria responsabilidades no sucesso alcançado pel'O Mosquito. Marcelo Balaban afirma que foi

\footnotetext{
9 Diversos autores mencionam os desentendimentos entre Bordalo e Agostini, sobretudo em 1878 nas páginas d'O Besouro (1878-1879) e Revista llustrada (1876-1898). Cf. ARAÚJO. Emanoel (curadoria). Rafael Bordalo Pinheiro - o português tal e qual: da caricatura à cerâmica O Caricaturista. São Paulo: Pinacoteca do Estado, 1996; e FRANÇA, José-Augusto. Rafael Bordalo Pinheiro o português tal e qual. Lisboa: Livros Horizonte, 2007. 3.ed.
} 
n'O Mosquito que começaria a consolidar-se a carreira de Agostini, ali o caricaturista iria "ganhar mais notoriedade e foi este também o instante em que produziu desenhos mais diretamente políticos, no sentido de defender uma causa ou engajar-se em um movimento organizado" (BALABAN, 2005, p. 8). Além disso Agostini defendia ideais compartilhadas por Bordalo Pinheiro como a crítica a Monarquia, a defensa das ideias republicanas e o anticlericalismo. Este último foi tema pungente na publicação tanto sob o lápis de Agostini quanto do de Bordalo.

O desligamento de Agostini do jornal não o afastaria da atuação jornalística, poderia então representar concorrência ao novo ilustrador? Carneiro tranquilizaria Bordalo neste sentido tanto pelo fato da suposta perda de independência de Agostini, quanto pelas "finas qualidades dos desenhos" e "agudeza das ideias" de Bordalo. No entanto, a herança de Agostini certamente foi um "fardo" com o qual Bordalo teve de enfrentar-se. Esta estava nos números anteriores do periódico, no traço com o que o público se acostumara, na forma e em detalhes como a caracterização particular que a personagem-título ou personagem-narrador da revista tomou sob o lápis de Agostini. Mas também na concorrência iniciada a partir de 1876, quando começou a circular a Revista Illustrada (1876-1898), cujo lema era justamente "Liberdade, Igualdade e Imparcialidade". A acusação de imparcialidade ou comprometimento com o "poder" era o pior dos insultos que um caricaturista poderia receber. Nas trocas de farpas observadas na imprensa esta era uma injúria fartamente utilizada e imputada ao "outro", que na ocasião pudesse apresentar opinião contrária, ou entendida como adversária. Assim a acusação de Carneiro a Agostini, observada na carta a Bordalo, também foi atribuída a Bordalo por Agostini e vice-versa. No espólio documental do Museu Rafael Bordalo Pinheiro há uma carta de Bordalo, datada de 15 de novembro de 1878 , na qual este pede explicações a Agostini sobre a forma "ambigua" e as suspeitas que este estaria disseminando sobre ele. Afirma na carta que

\begin{abstract}
Nessa Revista, nem no Mosquito, quando era feito pelo mesmo desenhista, nunca se fez caricaturas nem artigos a pedido destes ou d'aquelles, por maior que fosse o empenho ou o interesse que ofereciam (BORDALO, 1878, grifo do autor).
\end{abstract}

O desentendimento com Agostini é apenas um dos capítulos dos muitos que Bordalo teve que escrever para construir sua história no Brasil. E a forma como ele atuaria na publicação para a qual foi contratado sãos os ingredientes para o começo dessa história.

\section{Estratégias de Bordalo n'O Mosquito}

A personagem-título d'O Mosquito, apresentado no primeiro número de 19 de janeiro de 1869, foi criado por Candido Aragonês de Faria (1849-1911), primeiro ilustrador e proprietário da publicação até, pelo menos, 1871. A ilustração mostra um homem de feições risonhas, com cabelo que lembra de um palhaço, com asas de mosquito, pairando sobre a cidade. Na mão direita segura um lápis litográfico e na esquerda um papel com o que seria o programa do periódico. Algo que chamaria a atenção na publicação foi a forma como Agostini se apropriaria desta personagem a partir de janeiro 1872. Esta teria grande destaque aparecendo em várias primeiras páginas. Na capa do n.172, de janeiro de $1872,{ }^{10}$ a personagem foi completamente transformada e humanizada ${ }^{11}$. Além de ter perdido as asas, foi vestida como uma espécie de arlequim. Manteria o lápis litográfico na mão e apareceu representada como se fosse o único personagem real em meio a vários brinquedos. Entretanto, cada um dos brinquedos evocava não o universo infantil, mas personagens ou temas da política e da sociedade brasileira do período. Na última página desse mesmo número a personagem aparece novamente, ocupando toda a página e varrendo

10 Disponivel em: http://memoria.bn.br/pdf/709654/per709654_1872_00121.pdf. Acesso em: 20 abr. 2020

11 O artigo faz referência a inúmeras imagens, diante da impossibilidade de reprodução de todas, optou-se por deixar algumas indicações através de links nas notas de rodapé, já que a maior parte dessas são páginas dos periódicos disponiveis em hemerotecas no Brasil e em Portugal. 
os desenhos que não teriam sido publicados anteriormente. Ou seja, indica uma nova fase, marcada pelo atual ilustrador do periódico, que criaria algo "singular" a partir dali. A aparência física com Angelo Agostini também é algo que chama a atenção, embora esse seja sempre apresentado como Mosquito e, mesmo que fosse um álter ego do caricaturista, é o personagem e não o autor. Conforme afirma Marcelo Balaban, "Agostini apostava no poder da imagem satírica de revelar a verdade, de despertar o leitor. O lugar de isenção, de independência, era o personagem narrador" (BALABAN, 2005, p. 169). Diferenciarse da personagem, segundo o autor, seria uma forma de "resguarda-se", pois o personagem seria mais que um "pseudônimo", "uma espécie de heterônimo de Agostini" (BALABAN, 2005, p. 169).

Enfrentar-se com um personagem tão marcante e ao mesmo tempo caracterizador do periódico foi um dos desafios de Bordalo em sua entrada na publicação. No n. 312 de 1875, no qual foi anunciada a chegada de Rafael Bordalo Pinheiro, é o Mosquito que o recepcionaria com um abraço. ${ }^{12}$ Como manter as características essenciais do jornal ilustrado, com as quais o público o reconhecia e, ao mesmo tempo, impor a sua marca? Sob o lápis de Bordalo a personagem, inicialmente, perderia espaço e protagonismo, no entanto passaria por adaptações até sua completa transformação. Reapareceria no n. 317 (BORDALO, 1875, p. 3), de maneira diminuta, no canto inferior direito da página do jornal,13 convidando o público a decifrar uma charada. Suas características foram mantidas, assim como suas roupas de arlequim e a inseparável presença do lápis litográfico. No n. 321 (BORDALO, 1875. p. 3) aparecem dois personagens narradores: ${ }^{14}$ o Mosquito e o Mephistopheles, ${ }^{15}$ ainda em pequena dimensão, ambos com lápis litográfico. Colocar juntos personagens de duas publicações também parece indicar ao público o desejo de diálogo e aproximação com outras publicações.
É importante lembrar que o Mephistopholes seria absorvido pel' O Mosquito, assim como Faria, seu ilustrador, retornaria à publicação que fundara em dezembro de 1875. No n. 323, também de 1875, a personagem é mostrada cumprimentando uma nova folha que nascia ${ }^{16}$ : Epocha. E na mesma página, logo abaixo, reaparece bem pequeno, segurando um imenso lápis litográfico, muito maior que ele. Seria uma indicação que a personagem era menor que o ilustrador? No n. 325 apresenta uma postura muito clara a respeito da atuação do ilustrador e do narrador no periódico. O caricaturista se representa ao lado da personagem-título da revista reverenciando a publicação que acabara de surgir.

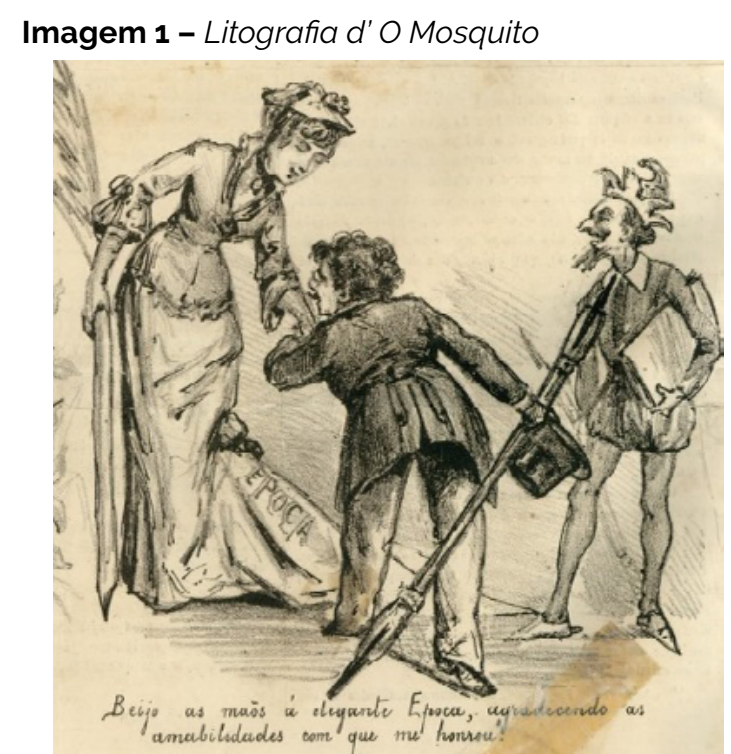

Fonte: (BORDALO, 1875, p. 2).

Na Imagem 1, embora Bordalo estivesse de costas, o lápis litográfico em sua mão tem grande destaque. Mais recuado, apenas observando a cena, vemos o Mosquito, cujo lápis litográfico está quase apagado. Este também segura uma pasta onde traria seus trabalhos anteriores, agora devidamente guardados. Bordalo parece dizer ao público que é o novo ilustrador do jornal e que o narrador da folha estaria agora aos seus serviços, submetido ao seu lápis litográfico. Ao diferenciar-

\footnotetext{
Disponivel em: http://memoria.bn.br/pdf/709654/per709654_1875_00312.pdf. Acesso em: 28 abr. 2020.

Disponivel em: http://hemerotecadigital.cm-lisboa.pt/Periodicos/omosquito/1875/N317/N317_item1/P3.html. Acesso em: 28 abr. 2020.

Disponivel em: http://hemerotecadigital.cm-lisboa.pt/Periodicos/omosquito/1875/N321/N321_item1/P2.html. Acesso em: 28 abr. 2020.

Personagem da folha ilustrada Mephistopheles que circulou entre 1874 e 1875 ilustrada por Cândido Aragonês de Faria.

Disponivel em: http://hemerotecadigital.cm-lisboa.pt/Periodicos/omosquito/1875/N323/N323_item1/P3.html. Acesso em: 28 abr. 2020.
} 
se da personagem, anteriormente associada a Agostini, coloca-se como o protagonista desta nova fase da publicação.

A partir de janeiro de 1876, Bordalo reconstruiria totalmente o narrador, inserindo-o na capa da publicação. ${ }^{17}$ O Mosquito vai aparecer caracterizado como um indigena, seu rosto de perfil deixa perceber um formato levemente arredondado. A versão arredondada do rosto será confirmada a partir do n. 348, quando o cabeçalho passa a apresentar uma versão sintetizada, ${ }^{18}$ ocupando apenas a parte superior da primeira página. Nessa versão a personagem perde os adereços indígenas retornando a sua vestimenta anterior. Antes disso, no n. 332 publicado em 12 de janeiro de 1876, o Mosquito resolve cumprimentar ${ }^{19}$ duas colegas que tinham surgido naquele Ano a Revista Ilustrada de Angelo Agostini e O Figaro, ilustrado por Borgomainerio. Na imagem Bordalo transforma-se no Mosquito, no entanto, o corpo deste adquire a forma do inseto e o rosto humano com monóculo - característica de Bordalo - não deixa dúvida de que era o próprio caricaturista que cumprimentava os personagens narradores das duas publicações.

A personagem Mosquito também reapareceria como protagonista e, em grande formato, lembrando os tempos de Agostini, mas não pelo lápis de Bordalo. Quem daria espaço ao narrador foi Faria, que voltou a colaborar no periódico entre final de 1875 até agosto de 1876. Nessa retomada da personagem Faria também the impõe mudanças na fisionomia. Isso pode ser observado nas páginas centrais ${ }^{20}$ do n. 329_e na capa ${ }^{21}$ do $n$. 349. ambos de 1876. Seu rosto não lembra nem a personagem do primeiro número e, muito menos, aquela de Agostini. Em muitos números ilustrados por Faria a personagem será evocada sempre a apontar para os problemas. Porém, algo curioso ocorreu no n. 349, Faria representou a personagem de monóculo 22 , acessório utilizado por Bordalo e muito presente em suas representações. Faria parece indicar que o lápis d'O Mosquito era de Rafael Bordalo Pinheiro.

No n. 380 de 26 de agosto de 1876, momento em que já era o único ilustrador da publicação, Bordalo parece sentir-se totalmente seguro para dar ao personagem feições particulares, indicando para o público que um "novo" Mosquito seria o interlocutor a partir daquele momento ${ }^{23}$. Escolhe então fazer uma conversa com o político anticlerical e maçom Saldanha Marinho (18161895) na sequência de imagens intitulada "A igreja e o Estado. Conversa do "Mosquito" com o sr. Conselheiro Saldanha Marinho". A personagem lembra a figura do cabeçalho sintetizado do $\mathrm{n}$. 348, mas também outra criação de Bordalo, o "Zé Povinho". No entanto, aparece vestido com as roupas tradicionais da personagem Mosquito, além disso, usa o monóculo. No n. 382 de 1876 a personagem ganha a capa da publicação ${ }^{24}$ e para não levantar dúvidas no público de que tratara-se do Mosquito, o representa sentado sob a pasta de desenhos com o nome da publicação e tem aos seus pés o lápis litográfico A semelhança com "Zé Povinho" parece mais clara ainda no n. 407 de 1877 no qual a personagem aparece representada na mesma página ${ }^{25}$. Além da semelhança entre o rosto do Mosquito com o "Zé Povinho", a própria postura que o narrador da folha assume, dialoga com a criação anterior de Bordalo. E a apropriação total do Mosquito aconteceria na capa do n. 412_de 1877.

\footnotetext{
Disponivel em: http://hemerotecadigital.cm-lisboa.pt/Periodicos/omosquito/1876/N329/N329_item1/index.html. Acesso em: 28 abr. 2020 Disponivel em: http://hemerotecadigital.cm-lisboa.pt/Periodicos/omosquito/1876/N348/N348_item1/index.html. Acesso em 28 abr. 2020. Disponivel em: http://hemerotecadigital.cm-lisboa.pt/Periodicos/omosquito/1876/N332/N332_item1/P4.html. Acesso em 28 abr. 2020.

20 Disponivel em: http://hemerotecadigital.cm-lisboa.pt/Periodicos/omosquito/1876/N329/N329_item1/P4.html. Acesso em: 28 abr. 2020.

1 Disponivel em: http://hemerotecadigital.cm-lisboa.pt/Periodicos/omosquito/1876/N349/N349_item1/index.html. Acesso em: 28 abr. 2020.

22 Disponivel em: http://hemerotecadigital.cm-lisboa.pt/Periodicos/omosquito/1876/N349/N349_item1/P4.html; Acesso em: 28 abr. 2020.

23 Disponivel em: http://hemerotecadigital.cm-lisboa.pt/Periodicos/omosquito/1876/N380/N380_item1/P4.html. Acesso em: 28 abr. 2020.

24 Disponivel em: http://hemerotecadigital.cm-lisboa.pt/Periodicos/omosquito/1876/N382/N382_item1/index.html. Acesso em: 28 abr. 2020.

25 Disponivel em: http://hemerotecadigital.cm-lisboa.pt/Periodicos/omosquito/1877/N407/N407_item1/P4.html. Acesso em: 28 abr. 2020.
} 


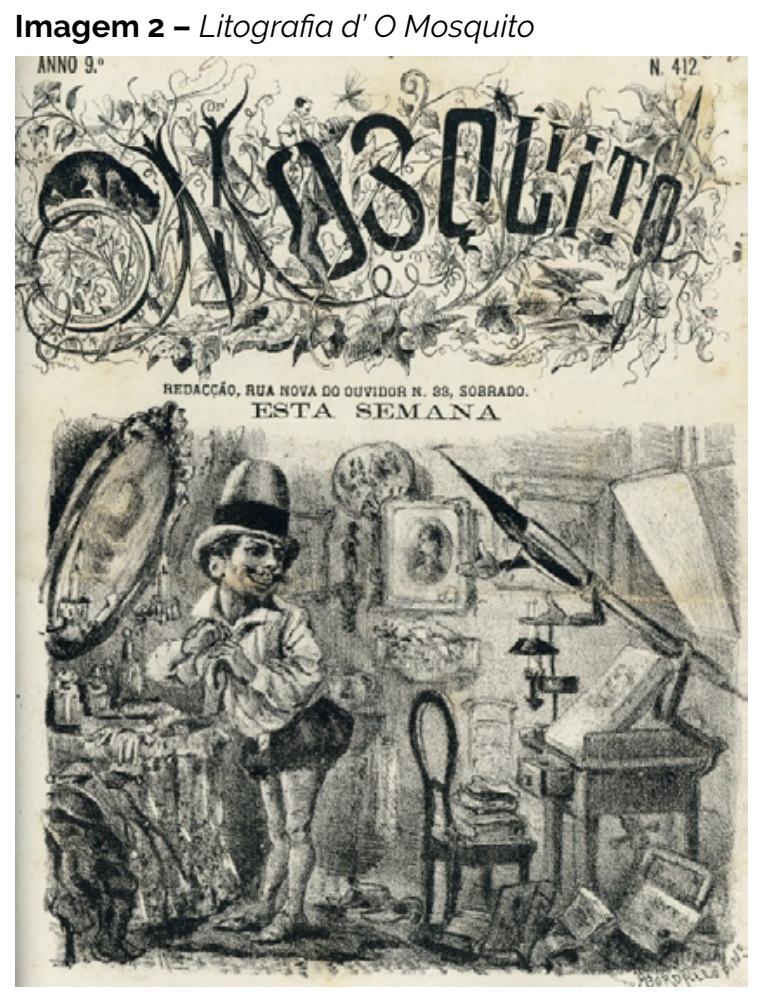

Fonte: (BORDALO, 1877, p. 1).

O caricaturista deu a personagem protagonismo e destaque na primeira página. Os traços do rosto são distintos das representações anteriores assim como seu vestuário. Na ilustração o Mosquito aparece em um momento de grande intimidade ao vestir-se diante de um espelho. A imagem reúne elementos de um ambiente doméstico e de trabalho. O universo do ilustrador e do narrador foram reunidos e apresentados ao leitor em um momento de fusão. O Mosquito está dialogando com o lápis litográfico, que por sua vez está apoiado sobre uma mesa de trabalho na qual se encontra a pedra litográfica. Aqui são explicitadas as caracteristicas inúmeras vezes atribuidas a Bordalo em torno de sua vaidade pessoal e cuidado extremo com sua aparência. O lápis surpreendido com tanta preparação para o Mosquito começar a trabalhar fala: "Ah então é calçar, enfeitar, barbear, enfarpelar, saudar, respirar... para trabalhar, tudo relacionar para depois contar" (BORDALO, 1877. p. 1). Na imagem é representada a metamorfose do artista em personagem, pois embora este ainda esteja usando o chapéu de Bordalo, o de arlequim do Mosquito aparece no primeiro plano à esquerda. Depois de quase 100 números a frente das ilustrações da publicação, com seu traço totalmente reconhecido pelo público, já poderia deixar-se confundir com o narrador, $O$ Mosquito era seu. ${ }^{26}$

\section{Os autorretratos de Bordalo}

Outra estratégia adotada por Bordalo a fim de obter reconhecimento, inserção e distinção tanto no meio jornalístico quanto com os leitores d'O Mosquito foi através de sua autorrepresentação. Em vários momentos sua imagem apareceu no meio de suas criações, às vezes até brincando de esconde-esconde com seus leitores, já que surgia atrás de algo, de perfil e até mesmo de costas. Em sua estreia no n. 313 de 11 de setembro de 1875 . seu autorretrato ${ }^{27}$ aparece mais de uma dezena de vezes na sequência narrativa que criou para falar da viagem, de seu imaginário sobre o Brasil, de sua chegada e das primeiras impressões sobre a terra que o recebia. O autorretrato de Bordalo serviu na publicação, entre outras coisas, para estabelecer uma relação de proximidade, um diálogo com o público leitor. O artista era capaz de assumir o lugar de público, quando, por exemplo aplaudia um espetáculo ou reverenciava algum homenageado por seu jornal, mas também ao informar ao leitor que sofria tanto quanto ele pelo calor no Rio de Janeiro. Através de sua imagem podia dizer que, às vezes, faltavam-lhe ideias para ilustrar o jornal como nas páginas centrais do $\mathrm{n}$. 335 de 1876. Diante da pedra litográfica em branco o artista leva as mãos à cabeça ${ }^{28}$ sobre a seguinte legenda: "Triste massado com uma enorme pedra em frente de mim, com inmenso calôr, preguiça e sem saber que lhes hei de dize!" (BORDALO, 1876, p. 2). E, na cena seguinte aparece sentado 
em uma cadeira confortável a abanar-se com um leque. O artista também podia apresentar ideias muito criativas ao propor soluções para o calor fluminense. No n. 333 de janeiro de 1876 , colocou vários personagens do mundo político, artístico, religioso e da imprensa no Rio de Janeiro dentro de uma enorme ventarola que tomava as duas páginas centrais da publicação. ${ }^{29}$ Todos vestidos com quimonos e abanando-se também com leques, informando que a moda do Japão poderia ser útil no Brasil. Retratara-se fora do leque, no canto inferior direito, desenhando sobre a pedra litográfica. Deixaria ainda um recado ao leitor de que se a imagem não o fizesse rir, que a recortasse e a transformasse em uma ventarola, ao menos teria alivio para o calor.

De acordo com Pedro Bebiano Braga, em texto sobre o tema no site do Museu Rafael Bordalo Pinheiro, através da prática do autorretrato "o artista iria construindo a sua individualidade."30 Esse elemento de individualidade e diálogo com o público vai ganhando cada vez mais espaço na obra de Bordalo a ponto de seus dois empreendimentos "autorais" no Brasil (Psit!! e Besouro) terem sua imagem estampada na capa das publicações.

Em várias ocasiões Rafael Bordalo Pinheiro se autorrepresentaria ao lado de outros artistas do lápis. Um desses momentos e que foi muito importante em seu percurso pelo Mosquito, foi justamente quando anunciou a chegada de novos colaboradores para a publicação em 1875, no n. 326. Na metade superior da ilustração, apoiados no lápis litográfico d'O Mosquito aparecem os retratos das denominadas "três graças" 31 : Bordalo, Faria e Valle, ${ }^{32}$ com a promessa de fazer "rir até as pedras." Dos três caricaturistas o que menos assinou desenhos foi Valle, sendo sua última participação em março de 1876, no n. 347. A colaboração de Faria foi mais efetiva e duradoura (dez. 1875 ago. 1876). Durante esse periodo houve números ilustrados exclusivamente por um dos três artistas, em uma espécie de rodizio, alternando-se o ilustrador a cada número. Mas também houve números compartilhados entre eles, sobretudo entre Bordalo e Faria, que chegaram a dividir e criar juntos uma mesma página, sinal de colaboração e articulação de ideias. ${ }^{33}$

Outro momento de autorretrato ao lado de caricaturistas ocorreu em fevereiro de 1876. por ocasião de um desentendimento com José Ferreira de Menezes (1842-1881), folhetinista do Jornal do Commercio (1827 - aos dias atuais). Em artigo publicado em 30 de janeiro Menezes aconselhou aos caricaturistas Bordalo, Borgomainerio, Agostini e, também Faria, a preservarem as figuras dos heróis nacionais como o Duque de Caxias 34 (1803-1880). O desenho que causou incômodo ao folhetinista foi publicado em 1876, no n. 336 d'O Mosquito e, mostrava os ministros do $27^{\circ}$ Gabinete ${ }^{35}$ do Império, entre eles o Duque de Caxias, com corpos de macacos ${ }^{36}$. A ilustração tinha a assinatura de Faria, no entanto o folhetinista não comentaria a atuação de Faria, mas de cada um dos três estrangeiros, atribuindo-lhes características. Fala do "talento de Borgomainerio" e da "Phantazia do verdadeiro poeta do Sr. Bordallo Pinheiro". Sobre Agostini afirma que este era proprietário do seu jornal, portanto "é entre todos os seus competidores quem está mais no caso de saber quanto são damnosos os golpes no ar e as ferroadas excessivas" (MENEZES,1876, p. 1). Tal

\footnotetext{
29 Disponivel em: http://hemerotecadigital.cm-lisboa.pt/Periodicos/omosquito/1876/N333/N333_item1/P4.html. Acesso em: 28 abr. 2020.

30 Disponivel em: https://museubordalopinheiro.pt/rafael-bordalo-pinheiro/autorretrato/. Acesso em: 28 abr. 2020

31 Disponivel em: http://hemerotecadigital.cm-lisboa.pt/Periodicos/omosquito/1875/N326/N326_item1/P2.html. Acesso em: 28 abr. 2020.

32 Antônio Alves do Valle de Sousa Pinto (1846-1921) também era português. Dos três artistas apresentados foi o que teve menor quantidade de desenhos assinados na folha ilustrada.

33 Embora não seja possivel desenvolver neste artigo, é importante mencionar que as relações de colaborações entre Faria e Bordalo também foram frutiferas e merecem ser aprofundadas, sobretudo no periodo em que ambos trabalharam n'O Mosquito.

34 Luís Alves de Lima e Silva foi político, monarquista e figura que se destacou em episódios militares como na Independência de Portugal, na Guerra Cisplatina e na contenção de revoltas durante o periodo regencial (1831-1840). Foi membro do Partido Conservador e Presidente do Conselho de Ministros.

$35 \mathrm{O} 27 .^{\circ}$ Gabinete era composto por representantes do partido Conservador: Duque de Caxias - Presidente e Ministro da GUERRA; José Bento da Cunha e Figueiredo (Visc. Bom Concelho) - IMPÉRIO; João Maurício Wanderley (Barão de Cotegipe) - FAZENDA; Tomás José Coelho de Almeida - AGRICULTURA; Diogo Velho Cavalcanti (Visc. de Cavalcanti) - JUSTIÇA; Luiz Antonio Pereira Franco (Barão Pereira Franco) - MARINHA.

36 Disponivel em: http://hemerotecadigital.cm-lisboa.pt/Periodicos/omosquito/1876/N336/N336_item1/P4.html. Acesso: 28 abr. 2020.
} 
atitude evidencia a importância e repercussão dos trabalhos destes profissionais no periodo e, a comparação entre eles, demonstra como seus trabalhos eram confrontados, algo que certamente fomentava a competitividade, citada pelo próprio Menezes. A citação nominal dos três caricaturistas, que nem eram os autores do desenho, fez levantar o debate em torno da atuação dos caricaturistas estrangeiros na imprensa e as respostas não tardariam a chegar.

Angelo Agostini foi o primeiro a manifestarse em um artigo intitulado "Ao folhetinista do Jornal do Commercio", publicado na Gazeta de Notícias. No texto, além de defender o trabalho dos artistas do lápis, o caricaturista fez o seguinte questionamento: "Será justa essa censura feita a nós caricaturistas estrangeiros, se desejando seguir os costumes do paiz, tomamos por norma o que dizem e fazem as folhas nacionais" (AGOSTINI, 1876, p. 2). Em carta publicada n'O Figaro e endereçada a A. de Almeida, proprietário daquela publicação, Borgomainerio afirmaria com indignação que "A vida de um artista, e especialmente a de um caricaturista fóra de seu paiz, é tão cheia de espinhos, que bem dispensa o mais agudo, isto é o de ser apontado ao publico como desrespeitador daquela que deve ser para ele uma segunda pátria!" (BORGOMAINERIO, 1876, p. 46). Bordalo foi o último a se manifestar porque estava doente, mas sua resposta deuse através de texto e imagem. Na capa do n. 341 de 1876 Bordalo representou o jornalista Ferreira de Menezes em cima do folhetim do Jornal do Commercio oferecendo tabaco ${ }^{37}$ aos três caricaturistas estrangeiros que foram citados no $\operatorname{artigo}^{38}$. Borgomainerio aparece em primeiro plano, Agostini no meio e Bordalo atrás, cada um com seu lápis litográfico e todos aceitando o tabaco. Todos escreveram respostas, mas Bordalo foi o único dos três ${ }^{39}$ que os representou diante do seu "algoz" - Agostini fez uma pequena representação, mas apenas dele e de Menezes. Colocar-se ao lado dos artistas considerados "os melhores" naquele ofício, foi também uma maneira de dizer ao público que era tão capaz quanto os outros. O bom humor observado na ilustração transformara-se em seriedade e rigor na resposta escrita pelo caricaturista. Bordalo evoca a história da caricatura advertindo que "não há manifestação artística sem finalidade moral" (BORDALO, 1876, p. 3). Segue falando de sua trajetória internacional, de seu compromisso em sempre se responsabilizar por suas publicações assinando-as. Concorda e cumprimenta os escritos dos colegas não sem antes afirmar que:

Eu sei que a sociedade em que vivo arvorou de ha muito em dogma a hospitalidade franca, verdadeira e amiga: e porque se the aflora assim a bondade proverbial e distinctissima, tem direito tambem a que o hospede the vote, sincera e lealmente, com todo o reconhecimento, todo o seu respeito (BORDALO, 1876, p. 3).

O debate em torno do tema do estrangeiro retornaria em outros momentos na obra de Bordalo n'O Mosquito, levando-o a criar a personagem "Manel Trinta Botões", do qual não trataremos neste artigo.

Através de um autorretrato o artista falaria para o público de seu gosto, de seus interesses e, por que não de suas paixões. Em um detalhe da ilustração do n. 341 d'O Mosquito Bordalo representara-se pintando ao ar livre, sentado diante de um cavalete, em meio a natureza. $\mathrm{Na}$ legenda o artista afirma-se "cada dia mais realista e apaixonado pela natureza".

\footnotetext{
${ }_{37}$ O uso do tabaco em pó para ser aspirado (rapé) foi bastante difundido entre as diversas esferas sociais no Brasil no século XIX. O suporte para transportá-lo, a tabaqueira, poderia ser um artigo de luxo. Na legenda da imagem há a menção ao termo em francês "Bon Tabac". Esse remete ao século XVIII, na qual o "bon tabac" não seria para qualquer nariz. Ao escolher o termo em francês certamente o caricaturista satirizava o conselho que Ferreira de Menezes diz oferece "de graça" no artigo com a ideia do "bon tabac" oferecido aos artistas. 38 Disponivel em: http://hemerotecadigital.cm-lisboa.pt/Periodicos/omosquito/1876/N341/N341_item1/index.html. Acesso em: 28 abr. 2020

39 Cândido Aragonês de Faria também fez uma ilustração dos caricaturistas diante de Menezes n'O Mosquito, mas nas páginas internas da publicação, sem o destaque oferecido por Bordalo.
} 
Imagem 3 - Litografia d'O Mosquito

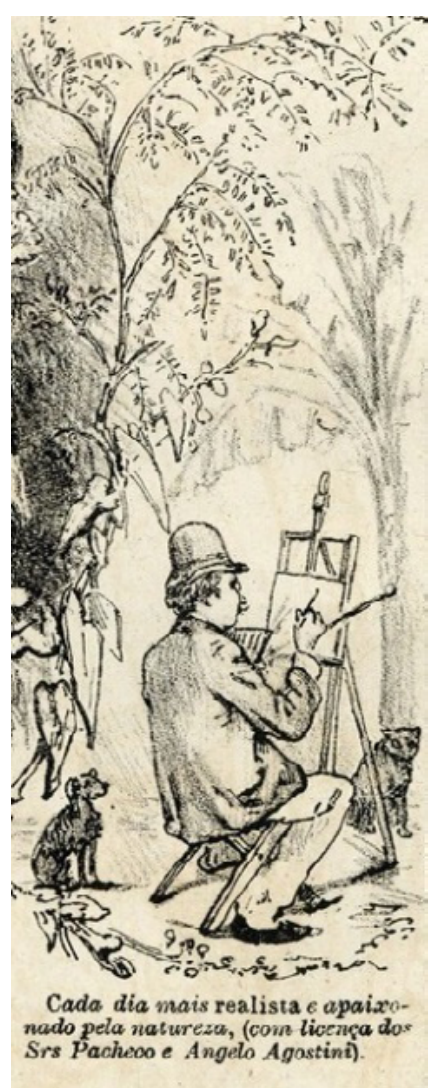

Fonte: (BORDALO, 1876, p. 2)

O deslumbramento de Bordalo com a natureza brasileira é algo digno de observação, pois a recorrência aos elementos naturais em seus desenhos é facilmente observada e certamente mais uma das estratégias de impor a sua marca e dialogar com o Brasil em suas publicações.

\section{Bordalo e a natureza}

O exemplo mais explícito do impacto da natureza na obra brasileira do artista talvez seja a intervenção feita na capa d'O Mosquito a partir de janeiro de 1876. Nessas ilustrações a natureza exuberante e vasta, assim como outros elementos entendidos como representantes do Brasil - o indígena, os pássaros, uma negra, a rede - são associados a publicação. Quando avançamos sobre trabalhos posteriores, só para ficar no Brasil, como Psit!! e O Besouro, a natureza esteve sempre presente nas capas, com grande protagonismo, além de compor diversas outras ilustrações ao longo da publicação. Só n'O Mosquito há vários exemplos, inclusive de como a natureza brasileira serviria como elemento de comparação. É o caso da ilustração denominada "Entre a Cruz e a Caldeirinha"40, publicada nas páginas centrais do n. 356_de 1876, cuja composição coloca o Brasil e Portugal em perspectiva através de diversos elementos. A discussão central da imagem é a questão da imigração, mas a forma como a natureza dos dois paises é apresentada chama a atenção. O lado português mostra uma vegetação pobre, sem vida, enquanto o lado brasileiro, apesar do grave problema que era a febre amarela, tem uma natureza exuberante. Outro exemplo onde a natureza tem grande protagonismo, embora também não seja o tema da discussão é em "O Beijo de Judas", publicada em 1876, no n. 358. Os dois terços superiores da ilustração representam o denso interior de uma floresta ${ }^{41}$. A representação noturna trata do tema, que talvez seja, o mais debatido e ilustrado na história do periódico: a "Questão Religiosa" (1872-1875).42 O jornal debate a questão através de críticas em torno da relação do Estado com a Igreja, assim como defende o papel da maçonaria enquanto instituição "iluminadora" e "guardiã" do progresso do país em sua luta contra o que seria o "obscurantismo" representado pela Igreja. A cena que ocorre no centro da composição mostra o Brasil, em alegoria indigena, ${ }^{43}$ sendo beijado pelo papa. A luz que permite ao leitor

\footnotetext{
40 Disponivel em: http://hemerotecadigital.cm-lisboa.pt/Periodicos/omosquito/1876/N356/N356_item1/P4.html. Acesso em: 29 abr. 2020. 41 Disponivel em: http://hemerotecadigital.cm-lisboa.pt/Periodicos/omosquito/1876/N358/N358_item1/P4.html. Acesso em: 29 abr. 2020. 42 Sobre a "Questão Religiosa" e os embates com a Maçonaria Cf. SANTOS. J. M.L.: SOFFIATTI, E. As contestações da liberdade. A Maçonaria e a Internunciatura Apostólica no Brasil do século XIX. REHMLAC+, v.7., n.1, maio/nov. 2015, p. 37-64. Disponível em: file:///C:/Users/ USER/Documents/o\%20"Mosquito"/igreja\%20e\%20ma\%C3\%A7onaria\%20brasil\%20seculo\%20xix.pdf. Acesso em: 28 maio 2019

43 A alegoria indígena, como representante no Brasil, foi recorrentemente utilizada durante o século XIX, sobretudo pelo movimento romântico que criaria uma imagem idealizada. Essa imagem fazia parte do esforço de construção de símbolos para uma história nacional e a imprensa teve um papel importante nesses debates. A imprensa ilustrada recorreu em diversos momentos a essa figura, propondo leituras críticas do país através de ações sobre o corpo idealizado desse indígena. Caricaturistas como Henrique Fleiuss e Angelo Agostini usaram amplamente essa figura em seus trabalhos, entre outros artistas no século XIX. Além disso, o governo imperial de D. Pedro II encomendou ao escultor Francisco Manuel Chaves Pinheiro (1822-1884), a obra Alegoria do Império Brasileiro (1871) no qual aparece um homem seminu com adornos indígenas. A obra está no Museu Nacional de Belas Artes do Rio de Janeiro.
} 
ver o que ocorre emana de uma tocha sustenta pela febre amarela, cujo rosto é de uma caveira. Há ali várias figuras da política, mas apenas uma delas indignada com o que via: o político, anticlerical e maçom Saldanha Marinho. Levar o debate para o centro de uma floresta parece ter sido a estratégia do caricaturista em ressaltar a importância da questão e como ela estava entranhada nas vísceras do país. Daí a importância de recorrer a alegoria indígena no que seria o seu habitat natural ou o mais característico símbolo nacional. Quando recorremos a iconografia sobre o Brasil a natureza era e, talvez continue sendo, o grande motivo, inúmeras vezes associado a própria identidade do país, tendo estampado telas de diversos artistas interessados no Brasil. O encantamento de Bordalo pela natureza, permanece em sua produção posterior. O olhar do artista para os elementos vegetais jamais deixaria sua produção, inclusive a cerâmica, não analisada neste artigo.

A passagem de Bordalo pel'O Mosquito pode ser entendida como momento criativo de compartilhamentos, experimentações e amadurecimento. Ao ter que lidar com o peso de heranças anteriores, conforme mencionado acima, o artista precisava mostrar que tinha habilidades e conhecimentos para seguir e manter com o sucesso do empreendimento. Para isso era fundamental conhecer o que a folha ilustrada produzira até então e dialogar com esse percurso. Também era importante saber o que outros periódicos ilustrados produziam, afinal a concorrência fazia-se presente cotidianamente. Além disso, precisava mostrar o seu talento e dar sua contribuição a publicação. A forma como lidou com a personagem-título da folha ilustrada parece ter sido uma boa estratégia de atuação, mas certamente era preciso mais. Quando folheamos as páginas d'O Mosquito, a partir do início da colaboração de Bordalo, é possivel perceber proposições visuais bastante distintas. Há desde ilustrações elaboradas, com características fotográficas até composições com traços rápidos e precisos, os quais tanto podem ter a leveza e graça necessárias para despertar o riso fácil quanto a crítica satírica. Seu traço é capaz de ir do realismo da composição, passando por jogos de luz e sombra até esquemas rápidos com traços apenas sugeridos. Através da versatilidade do seu desenho demonstrava destreza no desenho e uso de técnicas como do sfumato, tal qual outros artistas como Agostini e Faria faziam. Mas também a singularidade de seu traço apresentando marcas pessoais, ousando e brincando com seu lápis litográfico. Sua forma de desenhar não foi linear e variava entre um desenho e outro, algo que certamente contribuiu para o diálogo com outros colegas de profissão. Apresentaremos aqui um exemplo, sua breve relação com o artista Luigi Borgomainerio, citado e reconhecido por Bordalo como mestre.

\section{Bordalo e Luigi Borgomainerio}

A amizade e identificação de Bordalo com o caricaturista italiano parece ter sido imediata a sua chegada. Não há indícios de que se conheciam antes e a morte prematura de Borgomainerio em março de 1876 abreviou as possibilidades de convivência. ${ }^{44} \mathrm{~A}$ aproximação entre Borgomainerio e Bordalo também passa pelos retratos. 0 caricaturista italiano saudaria o caricaturista português com uma ilustração nas páginas centrais do n. 406 da Vida Fluminense de 1875. na qual Bordalo aparece sentado sobre um cavalinho de papel45 - O Mosquito -, muito elegante e com o característico monóculo e chapéu presença constante em representações do artista. Algo curioso nessa imagem é a semelhança da posição de Bordalo na imagem com uma ilustração criada por este em 1875, no n. 32 da Lanterna Mágica. Na cena criada em Portugal quem está sentado é o Rei D. Luís I (1838-1889) e, sobre um barco46,

\footnotetext{
44 Borgomaineiro foi vítimas da febre amarela. Em fevereiro de 1876 Bordalo também foi acometido pela doença. Ter vivenciado a mesma experiência do amigo é mais um elemento que os aproximaria.

45 Disponivel em: http://memoria.bn.br/pdf/709662/per709662_1874_00406.pdf. Acesso em: 29 abr. 2020.

46 Disponivel em: http://hemerotecadigital.cm-lisboa.pt/Periodicos/LanternaMagica/N32/N32_item1/P3.html. Acesso em: 29 abr. 2020.
} 
mas como se conduzisse um cavalo47. Ao citar a imagem Borgomainerio poderia indicar ao colega que conhecia e apreciava sua produção anterior, logo, homenageando-o duplamente. Bordalo retribuiria a gentileza retratando o caricaturista italiano no n. 318 d'O Mosquito. Borgomainerio aparece montado sobre o $\mathrm{F}$ do nome da revista ${ }^{48}$, e logo abaixo, em formato menor, Bordalo reproduz o seu retrato, com o chapéu na mão agradecendo ao colega.

No dia 4 de março de 1876, em seu número 346, O Mosquito publicou uma nota acerca do falecimento do artista na qual afirmava que "Borgomainerio não tinha ainda quarenta annos, e o seu talento, em pleno vigor, produzia sem a menor fadiga aquelas magnificas concepções que a Vida Fluminense e O Figaro e nas quaes se via o cunho do seu fino sentir e do seu grande saber." (O Mosquito, 1876, p. 2). O número seguinte foi ilustrado por Faria e Valle, sendo este último o encarregado em fazer a homenagem ao caricaturista nas páginas centrais do jornal. Valle 49 reproduziu o último desenho ${ }^{50}$ de Borgomainerio publicado n'O Figaro, ${ }^{51}$ assim como seu Retrato e uma imagem da viúva diante do túmulo. No n. 348 de 1876 _Bordalo torna a ocupar as duas páginas centrais da publicação com uma ilustração complexa e cheia de citações. A medalha com o rosto e o nome do amigo foi colocada entre os grandes representantes da arte da caricatura como Daumier, Goya, Hogarth, Gavarni. Evoca na imagem a nostalgia da terra natal, tal qual a sua própria, mostrando Borgomaineiro olhando um navio que ia ao longe ${ }^{52}$. Também é mostrado sem vida assim como o corpo de uma mulher, em desespero e abraçada por um pássaro negro, talvez a esposa tomada pela dor. Há ainda diversas alegorias, coroas de flores, o lápis litográfico coberto por um pano negro. A parte inferior do desenho tem espinhos entrelaçados, inclusive uma paleta de pintor. Há corvos, uma partitura com o Requiem de Giuseppi Verdi, e personagens narradores como o Mosquito, com os braços estendidos, em gesto de agradecimento. O sentimento expresso na imagem, assim como a inscrição "A memória do meu querido mestre e amigo Borgomainerio" (BORDALO, 1876, p. 5), demonstram como Bordalo lhe devotava afeto e admiração.

As citações e diálogos com o caricaturista italiano foram além dos retratos e da homenagem pós morte e podem ser observadas também em outras ilustrações criadas por ambos. Em agosto de 1875. uma semana antes da chegada de Bordalo ao Brasil, Borgomainerio usou as páginas centrais do n. 400 da Vida Fluminense para ilustrar o que ele chamou de "Annuncios grátis"53. Na imagem apresentava o jornal que começava a circular na Corte: A Gazeta de Notícias, empreendimento do mesmo proprietário d'O Mosquito. A ilustração brinca com o impacto que a leitura do jornal causaria no "bom povinho", o qual agora teria achado "finalmente o seu orgam" (BORGOMAINERIO, 1875, p. 274). Na Imagem há vários personagens lendo, entre eles uma mulher negra e o próprio planeta terra, todos absorvidos na leitura da Gazeta de Notícias. Há na ilustração um interesse por tipos populares como a própria ideia de um "povinho", mas também no homem magro ao lado do gordo, da mulher negra, assim como o fato de a leitura tornar-se algo apreciado pela população. Embora de forma sútil, o caricaturista parece chamar a atenção para a importância da alfabetização como forma de emancipação dos povos. Demonstra isso ao falar de "milagres que se esperam" mostrando uma figura cômica abraçada a um exemplar da publicação. Na obra de Bordalo observamos um grande interesse por tipos populares assim como um discurso favorável a educação do povo. Na renovação da capa d'O

47 O Rei D. Luis foi educado para ser oficial da Armada e só assumiu o trono após a morte do irmão.

48 Disponível em: http://hemerotecadigital.cm-lisboa.pt/Periodicos/omosquito/1875/N318/N318_item1/P2.html. Acesso em: 29 abr. 2020.

49 O retrato do artista publicado no n. 11 d'O Figaro também foi feito por Valle a partir de uma fotografia de Joaquim José Insley Pacheco (1830-1912)

50 Disponivel em: http://hemerotecadigital.cm-lisboa.pt/Periodicos/omosquito/1876/N347/N347_item1/P4.html; Acesso em: 29 abr. 2020. 51 Por ironia do destino a imagem de Borgomainerio retratava a morte de um casal de jovens afogados em uma praia do Rio de Janeiro A cena era contornada pela alegoria da morte e da esperança e mostrava o desespero da mãe da jovem abraçada ao cadáver da filha.

52 Disponivel em: http://hemerotecadigital.cm-lisboa.pt/Periodicos/omosquito/1876/N348/N348_item1/P4.html. Acesso em: 29 abr. 2020.

53 Disponivel em: http://memoria.bn.br/pdf/709662/per709662_1874_00400.pdf. Acesso em: 29 abr. 2020. 
Mosquito 54 a partir de janeiro de 1876 vemos uma citação dessa imagem, tanto na ideia do interesse que o jornal despertaria na população quanto na representação de personagens. Bordalo colocou os números d'O Mosquito nas mãos de indígenas, de uma mulher branca deitada na rede, e, assim como Borgomainerio, nas mãos de uma mulher negra.

O uso da música para as metáforas políticas é outro ponto comum entre os artistas. Em janeiro de 1875, nas páginas centrais do n. 367, Borgomainerio criaria a "Bibliotheca útil da Vida Fluminense. Lições de Música aplicadas ao nosso tempo por D. Ciccio"55. Além de reproduzir vários instrumentos musicais, alguns sendo utilizados, o caricaturista também criaria uma escala musical ${ }^{56} \mathrm{com}$ rostos de políticos do Império, sendo o primeiro o de $D$. Pedro II. Também utilizou a ideia da orquestra em 1875 no n. 402, com a alegoria do Brasil regendo políticos ${ }^{57}$. Similar a criação de Bordalo de 1876 , nas páginas centrais do n. 354 d'O Mosquito, na qual a Princesa Isabel (1846-1921) regia a nação58. Luzia Rocha fez um estudo sobre a presença da música e da ópera n'O Antonio Maria (18791885; 1891-1898), publicação considerada a mais importante de Bordalo em Portugal. Segundo a autora "As 'citações' musicais que faz nos seus jornais são lógicas e coerentes, a teoria musical é utilizada de forma correctíssima e os instrumentos musicais são também usualmente representados com certa correcção" (ROCHA, 2010, p. 21). No n. 178 , de 26 de outubro de 1882, d'O Antonio Maria59 Bordalo também utilizaria uma pauta para criar uma escala musical com os rostos de politicos portugueses responsáveis pelo governo naquele momento ${ }^{60}$. Rocha afirma que
Nesta caricatura, Bordalo Pinheiro usa a música para caracterizar a política do país e a situação do povo português. O partido regenerador estava no poder, com um ministério presidido por Fontes Pereira de Melo. [...]. As notas de pauta são os políticos regeneradores. O preciosismo do desenho é tal que a escala começa em dó e acaba em dó, ou seja, começa em Fontes e acaba em Fontes. Para o dó mais grave Fontes tema a coroa de rei grande demais, de forma a fazer a linha suplementar inferior (ROCHA, 2010, p. 99).

A semelhança entre as imagens é instigadora inclusive no fato de que há destaque dos chefes políticos dos países, considerados responsáveis pelas mazelas das nações: Borgomaineirio destaca, além dos ministros do Império, D. Pedro II e, Bordalo, Fontes Pereira de Melo, ${ }^{61}$ ambos retratados como reis, embora só D. Pedro II o fosse de fato.

Assim como Bordalo recorreu a partes do corpo para dar ênfase em uma determinada característica, como os "Barrigas" - outra criação dos tempos d'A Lanterna Mágica, Borgmainerio também recorreu a esse recurso e usou tanto orelhas quanto olhos. Em 1875, no n. 377 da Vida Fluminense, o caricaturista italiano transforma a cabeça de um grupo de pessoas em grandes olhos $^{62}$, alertando para que ficassem atentos ao parlamento e na reforma eleitoral em processo naquele momento. Em 1876, no n. 336 d'O Mosquito Faria também utilizaria um corpo masculino elegantemente vestido com cabeça de olhos ${ }^{63}$, agora para se referir à Lavoura. No $n$. 341 do mesmo ano Bordalo também recorreria a cabeça em forma de olhos, mas agora com dois olhos ao invés de um, para falar do entusiasmo com relação a duas cantoras amadoras que teriam

\footnotetext{
54 Disponivel em: http://hemerotecadigital.cm-lisboa.pt/Periodicos/omosquito/1876/N329/N329_item1/index.html. Acesso em: 29 abr. 2020. Disponivel em: http://memoria.bn.br/pdf/709662/per709662_1874_00367.pdf. Acesso em: 29 abr. 2020

A escala musical faz referência aos rostos dos ministros do $26 .^{\circ}$ Gabinete Imperial, presidido por José Maria da Silva Paranhos, Visconde do Rio Branco entre 1871 e 1875.

57 Disponivel em: http://memoria.bn.br/pdf/709662/per709662_1874_00402.pdf. Acesso em: 29 abr. 2020.

58 Disponivel em: http://hemerotecadigital.cm-lisboa.pt/Periodicos/omosquito/1876/N354/N354_item1/P4.html. Acesso em: 29 abr. 2020. 59 Disponivel em: http://hemerotecadigital.cm-lisboa.pt/Periodicos/OAntonioMaria/1882/1882_item1/P303.html. Acesso em: 29 abr. 2020. 6o Luzia Rocha identifica entre os politicos ali representado Fontes Pereira de Melo, "José de Gomes Golveia (nota ré), Júlio Vilhena (nota mi), António de Serpa Pimentel (nota fá) e Hintze Ribeiro (a nota sol)" (ROCHA, 2010, p. 99).

61 António Maria Fontes Pereira de Melo (1819-1887) foi um nome fundamental e poderoso na politica portuguesa da segunda metade do século XIX. Esteve à frente do governo durante longos períodos, foi um dos chefes do Partido Regenerador entre 1871 e 1887 e, responsável por várias ações de modernização do país, assim como representou obstáculos aos republicanos. Foi alvo preferido de Bordalo Pinheiro e o político mais satirizado pelo caricaturista em Portugal. Cf.: MOITA, I. (org.). Fontes Pereira de Melo nas caricaturas de Bordalo Pinheiro. Lisboa: Museu Rafael Bordalo Pinheiro,1988.

62 Disponivel em: http://memoria.bn.br/pdf/709662/per709662_1874_00377.pdf. Acesso: 29 abr. 2020.

63 Disponivel em: http://hemerotecadigital.cm-lisboa.pt/Periodicos/omosquito/1876/N336/N336_item1/P4.html. Acesso em: 29 abr. 2020.
} 
cantado no coro da Missa Requiem de G. Verdi apresentada na corte sob organização do pianista Arthur Napoleão64. Nas páginas centrais do n. 362 de 1876, faz do olho um personagem em uma sequência narrativa ${ }^{65}$ de imagens onde brinca com a polícia e a figura mitológica de Argos (Aquele que teria cem olhos). A imagem faz referências às ações da policia para investigar um caso de notas falsas na Corte, a qual estaria inclusive invadindo, com seus olhos, a privacidade dos lares. Os olhos voltam a aparecer naquele mesmo ano no n. 364. ainda relacionados com a investigação sobre as notas falsas e o relatório que o chefe da polícia teria apresentado ${ }^{66}$. O uso de um mesmo recurso por três diferentes caricaturistas chama a atenção para possiveis colaborações e compartilhamentos de ideias entre os artistas.

A vivência compartilhada dos caricaturistas demonstra periodos de experimentação e troca, no qual ideias são compartilhadas, aperfeiçoadas e mesmo transformadas. As investigações visuais geraram aprendizagens que foram guardadas e reaproveitadas, não como cópias, mas como reinterpretações originais utilizadas em contextos especificos.

\section{Considerações finais}

Os anos iniciais de Bordalo no Brasil proporcionaram ao artista o contato com um ambiente distinto da sua Lisboa natal. Conheceu novas pessoas, publicações, realidades sociais, políticas e culturais que embora tivessem muito em comum com Portugal, sobretudo no âmbito da organização política, eram singulares. Com a responsabilidade de dar continuidade a uma publicação de sucesso e já bastante conhecida do público, dialogou com a história desta através, por exemplo, do tratamento de temas caros a publicação como o anticlericalismo desenvolvido pelo "passeur de culture" - Angelo Agostini. Mas também soube construir o seu espaço enquanto "mediador cultural" apresentando-se ao público não apenas através de seus "engraçados" autorretratos, mas criando personagens, adaptando o narrador do periódico e a própria composição gráfica da publicação. Criou um novo cabeçalho em 1876, com introdução de elementos há muito identificados com o Brasil como a natureza e o indígena, o qual, com algumas modificações permaneceria até o final da publicação. Além disso, o cabeçalho ostentava autoria com a presença constante da sua assinatura na primeira página, inclusive em números que não ilustrou, durante o periodo de colaboração de Faria e Valle. Há muito mais que poderia ser dito da experiência de Bordalo n'O Mosquito, assim como, certamente há muitas outras parcerias e convivências, para além do ambiente de trabalho, das quais não ficaram ou não foram encontrados registros e, que em muito contribuiriam para entender esses anos. $O$ estudo da produção de Rafael Bordalo Pinheiro impõe muitos desafios e um longo caminho a ser percorrido pelos interessados, esse artigo pretende oferecer apenas alguns passos.

Há uma fotografia de Bordalo de meados de 1877 que parece muito instigante para observar como o próprio artista se via depois de dois anos no Brasil (Imagem 3).

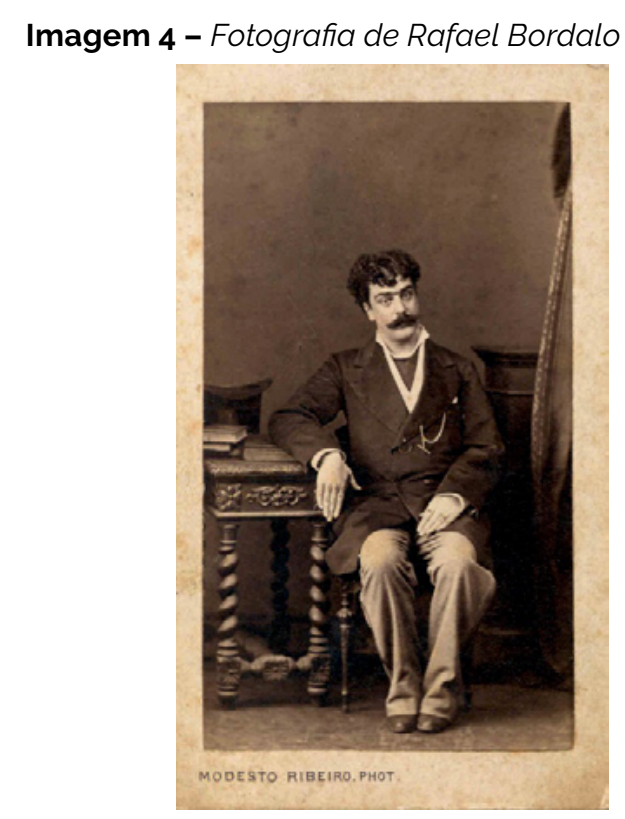

Fonte: Museu Rafael Bordalo Pinheiro. 
A imagem corresponde ao periodo em que foi encerrada a publicação d'O Mosquito, o último número foi publicado em 26 de maio de 1877. Mas também um momento no qual seriam iniciados novos projetos - o primeiro número da folha ilustrada Psit!! foi publicado em 15 de setembro daquele ano. Este foi o segundo jornal no qual o artista colaborou no Brasil, mas sua primeira iniciativa empresarial, seu projeto artístico e pessoal. Talvez um dos primeiros elementos concretos de uma "transferência Cultural", na qual vemos o talento de Bordalo, suas experiências e contatos estrangeiros, mas também muito do que aprendeu no Brasil. Na imagem Bordalo aparece sentado, elegantemente vestido, com o braço direito apoiado sobre livros que estão em uma pequena mesa na qual também se observa uma cartola. Seu olhar encara o espectador, tem um ar de fidalgo, mãos estendidas em uma pose propositadamente escolhida para fazer ver seus dedos cheios de anéis. Há na fotografa símbolos de conhecimento e esmero pessoal, os quais são reafirmados na imagem construida pelo artista. No verso da fotografia a seguinte dedicatória: "Ao meu querido pae offerece um que foi idealista e hoje negoceia e vende chouriços. Está rico mas triste. Um bom burgues" (BORDALO, 1877). Como todo imigrante que saia de Portugal em direção ao Brasil em busca de fortuna e reconhecimento, Bordalo parece querer demonstrar a sua familia que teria conquistado condição financeira confortável. A dedicatória reafirma a ideia do logro de, pelo menos um, dos seus objetivos: a riqueza. Entretanto, parece não estar completo, há tristeza. Nostalgia de sua terra natal? Contrariedades em sua atuação na imprensa? Independente de respostas Bordalo parece afirmar que estava valendo a pena a experiência e novas páginas dessa história ainda seriam escritas pelo caricaturista.

\section{Referências}

AGOSTINI, Angelo. Ao folhetinista do Jornal do Commercio, Gazeta de Noticias, Rio de Janeiro, ano II, n. 39 , 5 fev. 1876. Publicações a pedido, p. 2.

A VIDA Fluminense. Rio de Janeiro: [s. n.], 1875
BALABAN, Marcelo. Poeta do lápis: a trajetória de Ângelo Agostini no Brasil imperial - São Paulo e Rio de Janeiro - 1864-1888. 2005. Tese (Doutorado em História) - Instituto de Filosofia e Ciências Humanas (IFCH) da Universidade Estadual de Campinas (UNICAMP), Campinas, 2005.

BORDALO PINHEIRO, Rafael. ICarta enviada ao colega Agostini]. Destinatário: Angelo Agostini. Rio de Janeiro, 15 nov., 1878. 1 Carta. MRBP. ESP. DOC. 0029.

BORDALO PINHEIRO, Rafael. IFotografia enviada ao pail. Destinatário: Manuel M. Bordalo Pinheiro. Rio de Janeiro, c.1877. 1 Fotografia. Autor: Modesto Ribeiro. Coleção Museu Rafael Bordalo Pinheiro. MRBP.FOT.0822.

BORGOMAINERIO, Luigi. O Folhetim. O Figaro, Folha Ilustrada, Rio de Janeiro, n. 6, 1876, p. 46.

BRITO, Rômulo de J. F. Um traço sobre o Atlântico: o Brasil na obra caricatural de Rafael Bordalo Pinheiro (1870-1905). 2017. Tese (Doutorado em História) - Pontifícia Universidade Católica do Rio Grande do Sul (PUCRS), Porto Alegre, 2017.

CAMARATE, Alfredo. ICarta enviada ao amigo Bordalo Pinheiro]. Destinatário: Rafael Bordalo Pinheiro. Rio de Janeiro, 7 jul. 1875. 1 Carta. MRBP. ESP. DOC.0678.

CARNEIRO, Manuel R. [Carta enviada ao caricaturista Bordalo Pinheiro]. Destinatário: Rafael Bordalo Pinheiro. Rio de Janeiro, 7 jun. 1875. 1 Carta. MRBP. ESP. DOC.0677

COMPAGNON, Olivier. Influences? Modèles? Transferts culturels? Les mots pour le dire. In: América: Cahiers du CRICCAL, n'33, Les modèles et leur circulation en Amérique latine, v. 1. p. 11-20, 2005. Disponivel em: https:// www.persee.fr/docAsPDF/ameri_0982-9237_2005_ num_33_1_1701.pdf. Acesso em 18-05-2019. Acesso em: 20 maio 2019. https://doi.org/10.3406/ameri.2005.1701.

COMPAGNON, Olivier. L'Euro-Amérique en question. Comment penser les échanges culturels entre l'Europe et l'Amérique latine. In: Nuevo Mundo Mundos Nuevos, $p$. 1-14, 03 fév. 2009. Disponivel em: http://journals.openedition.org/nuevomundo/54783. Acesso em: 20 maio 2019. https://doi.org/10.4000/nuevomundo.54783.

COOPER-RICHET, Diana. Transferts culturels et passeurs de culture dans le monde du livre (France - Brésil, XIX siècle). Patrimônio e Memória, São Paulo, p. v. 9. n.1, p. 128-143, jan./jun. 2013. Disponivel em: http://pem.assis. unesp.br/index.php/pem/article/view/322. Acesso em 17 maio 2019

COTRIM, João Paulo. Rafael Bordalo Pinheiro Fotobiografia. Lisboa: Assírio e Alvim, 2005

FERRARI, Danilo W. Monteiro Lobato e a circulação (Inter)nacional de caricaturas. 2018. Tese (Doutorado em História) - Faculdade de Ciências e Letras da Universidade Estadual Paulista (Unesp), Assis, 2018.

FRANÇA, José-Augusto. Rafael Bordalo Pinheiro o português tal e qual. Lisboa: Livros Horizonte, 2007.

LIMA, Herman. História da Caricatura no Brasil. Rio de Janeiro: J. Oyimpio Editora, 1963. 
LOPES, Maria Virgilio Cambraia. Rafael Bordalo Pinheiro: imagens e memórias do teatro. Lisboa: Imprenta Nacional Casa da Moeda, 2013.

LUCA, Tania Regina de. A Ilustração (1884-1892): algumas questões teórico-metodológicas. In: ABREU, Márica.; DEAECTO, Mariza Midori. (org.). A circulação transatlântica de impressos: Conexões. Campinas-SP: Unicamp \AEL \setor de publicações, 2014. p. 167-174.

LUCA, Tania Regina D. Prefácio à Edição Brasileira. In: GUIMARÃES, Valéria (org.). Transferências culturais: o exemplo da imprensa na França e no Brasil. Campinas-SP: Mercado de Letras, 2012.

MENEZES, José F. de. Folhetim. Jornal do Commercio, Rio de Janeiro, ano 55, n. 30 de 30 de janeiro de 1876, p. 1.

O MOSQUITO. Rio de Janeiro: [S. n.], 1875.

PINHEIRO, Manuel M. B. [Carta enviada ao filho Manuel]. Destinatário: Manuel Bordalo Pinheiro. Alcolena - Lisboa, 16, abr, 1877. 1 Carta. Biblioteca Nacional de Portugal, Espólio familia Lopes de Mendonça, N53\2065.

PINTO, Manuel de Souza. Bordalo no Brasil. In: O Caricaturista Raphael Bordallo Pinheiro. Lisboa: Livraria Ferreira Editores, 1915, p. III.

ROCHA, Luzia. Ópera e Caricatura: O Teatro de S. Carlos na obra de Rafael Bordalo Pinheiro. Lisboa: Edições Colibri; Centro de Estudos de Sociologia e Estética Musical, 2010. v. 2.

\section{Rosangela de Jesus Silva}

Doutora em História da Arte pela Universidade Estadual de Campinas (UNICAMP, Campinas, SP, Brasil), professora da Universidade Federal da Integração Latino-americana (UNILA) em Foz do Iguaçu, PR, Brasil.

\section{Endereço para correspondência:}

Rosangela de Jesus Silva

Universidade Federal da Integração Latino-Americana. Instituto Latino-Americano de Arte, Cultura e História. Avenida Tarquínio Joslin dos Santos, 1000. Jardim Universitário

Foz do Iguaçu, Paraná - Brasil

CEP: 85.870-901 